\title{
Effects of breed, sex and diet and their interactions on fat deposition and partitioning among depots of broiler chickens
}

\begin{abstract}
The effects of breed (Hubbard and Anak), sex and diet (two levels of protein (high or low) with two levels of crude fiber (low or high) at each level of protein) on fat yields and partitioning among the depots were studied. No significant differences were found between breeds in fat yields and in fat partitioning among the major fat depots. Expressed as a percentage of live body weight, females had a greater percentage of non-carcass fat, carcass fat and total body fat than males. Females tended to partition more of their fat to non-carcass fat, whereas males tended to partition more of their fat to carcass fat. The effects of diet were consistent over the breeds and for all fatness traits. Non-carcass fat, carcass fat and total body fat yields were greatly depressed and favorable fat partition between depots was achieved through feeding birds high protein- high fiber diets. These birds tended to partition more of their fat to carcass fat depots (more valuables) and less to non-carcass fat depots. Breed $\mathrm{x}$ sex, breed $\mathrm{x}$ diet and sex $\mathrm{x}$ diet interactions did not significantly influence most of fatness traits indicating that the factors under consideration act independently of each other. Significant sex $\mathrm{x}$ diet interactions was found for carcass fat and total body fat relative to live body weight: the sexual dimorphism in low protein diet is more pronounced than in high protein diets. The differences between sexes in their response to diet for these traits might have important implications.
\end{abstract}

Key Words: Chicken, breed, sex, diet, fat yields, fat partition, genotype x nutrition interactions

\section{Zusammenfassung}

Titel der Arbeit: Einfluss von Rasse, Geschlecht sowie Fütterung auf den Fettansatz und die Fettverteilung geschlachteter Broiler

Untersucht wurde der Einfluss von Rasse (Hubbard und Anak), Geschlecht und Fütterung (niedriges und hohes Protein- bzw. Rohfaserniveau) auf den Fettgehalt und die Fettverteilung in den Körperdepots. Zwischen den Rassen ergaben sich keine signifikanten Unterschiede bezüglich des Fettgehaltes und der -verteilung in den wichtigsten Fettdepots. Bezogen auf das Lebendgewicht zeigten die weiblichen Tiere einen größeren prozentualen Anteil von Nicht-Muskelfett, Muskelfett und Gesamtkörperfett während die männlichen Tiere bei der Verteilung zu mehr Muskelfett tendierten. Beim Rassenvergleich fanden sich bezüglich des Fütterungseinflusses keine Unterschiede hinsichtlich der Fettmerkmale. Der Fettanteil und die -verteilung wurden bei sämtlichen Fettmerkmalen sowohl durch das höhere Protein- als auch Rohfaserniveau positiv beeinflusst. Hierbei tendierten diese Tiere zu mehr Muskelfett und weniger Fett in den Nicht-Muskeldepots. Interaktionen zwischen Rassen x Geschlecht, Rassen x Fütterung bzw. Geschlecht x Fütterung übten keinen signifikanten Einfluss aus und zeigten, dass sie unabhängig voneinander wirken. Signifikante Interaktionen ergaben sich lediglich für Muskelfett und Gesamtkörperfett in Bezug auf das Lebendgewicht. Der Geschlechtsdimorphismus war bei niedrigerem Proteinniveau ausgeprägter als bei hohem. Die Reaktion der beiden Geschlechter auf das unterschiedliche Protein- und Rohfaserangebot im Zusammenhang mit den untersuchten Fettmerkmalen weist auf die besondere Bedeutung dieser Fütterungsniveauunterschiede hin.

Schlüsselwörter: Broiler, Rasse, Geschlecht, Fütterung, Fettertrag, Fettverteilung, Rasse : Fütterung - Interaktion

\section{Introduction}

The increasing demand for leaner carcasses and decreasing demand for fat had made it imperative to choose the appropriate breeds, strains, crosses of greater genetic potential for live performance and carcass attributes and to develop different practical 
and profitable dietary regimes, which might result in a more desirable carcass composition. Fat partition among the major depots, included excessive amount of noncarcass fat at market age has become a commercial problem to all segments of meat industry, as it may influence yields, waste management, waste of dietary energy and consumers' acceptability i.e. increasing concern with diet health issues (HEATH, 1980; LEENSTRA, 1984; LEENSTRA et al., 1986).

Body composition in broilers can be manipulated through genetic and nutritional routes. Increasing protein: energy ratio resulted in increasing carcass leanness and decreasing body fatness with the opposite effect was elicited by a low protein: energy ratio (FISHER, 1984; LEESON et al., 1996; KHANTAPRAB et al., 1997; SMITH and PESTI, 1998; WISEMAN and LEWIS, 1998). The combined effects of breed, sex, and diet and their interactions on fat yield and fat partitioning have received little attention and partitioning of bird response due to these effects have not been widely reported. To test the hypothesis that the similarity of breeds and sexes in their response to diets, this study was designed to consider simultaneously the effects of breed-type, sex and diet and their respective interactions on fat yield and fat partitioning among the depots of broiler chickens.

\section{Materials and methods}

Five hundred and seventy six 1-d-old unsexed broiler chickens of two breeds (Hubbard and Anak) were used in this study. These birds were from the Poultry Nutrition Research Station, Department of Poultry Production, Ain Shams University. Chicks of each breed were divided equally into four groups, and randomly assigned to one of four diets treatment groups each contained 18 chicks in four replicates. The diets were formulated to contain two levels of protein (high or low) with two levels of crude fiber (low or high) at each level of protein. The ingredients and chemical composition of the four diets are given in Table 1.

All the diets were provided ad. libitum and conventional brooding and rearing practices were followed. Body weights, body weight gains, feed intake and feed: gain ratios were recorded weekly during 0-4 week stating period and for the 4-8 weeks finishing period.

At the end of the experiment (8 weeks of age), a representative samples of 72 (36male, 36 female) Hubbard and $75(38,37)$ Anak broilers fed each diet were selected at random for slaughter and dissection. The birds were fasted overnight prior to sacrifice, individually weighed and killed by severing the carotid artery and jugular veins. The head was removed at the atlanto-occipital articulation. After dry plucking, the birds were eviscerated, the feet and shanks were removed at the tibio-tarsus joint.The viscera were removed as for the usual dressing of poultry carcasses. The heart, liver (minus the gall bladder) and empty skinned gizzard were trimmed of extraneous tissue and weighed individually and their sum of weights 'giblets' was taken. Non-carcass fat 'abdominal fat' including fat surrounding gizzard, heart fat, fat trimmed from alimentary tract 'visceral fat' and pad fat was removed and weighed. Carcass yield 'dressing percentage' is obtained by expressing the dressed carcass weight (with or without giblets) as a percentage of live body weight. In each carcass the skin and subcutaneous fat was removed from the surface of the superficial muscles and intermuscular fat was removed from the indentation of their origin and insertion. The sum of the above depots 
at the carcass level is referred to as total carcass fat. Total body fat combined both total non-carcass fat and total carcass fat.

Table 1

Ingredients and composition of the experimental diets (Gehalte und Zusammensetzung des Versuchsfutters)

\begin{tabular}{|c|c|c|c|c|c|c|c|c|}
\hline \multirow[b]{3}{*}{ Item } & \multicolumn{4}{|c|}{$\begin{array}{c}\text { Starter diets } \\
(1-4 \text { weeks })\end{array}$} & \multicolumn{4}{|c|}{$\begin{array}{l}\text { Finisher diets } \\
\text { (5 - } 8 \text { weeks) }\end{array}$} \\
\hline & \multicolumn{2}{|c|}{ High protein } & \multicolumn{2}{|c|}{$\underline{\text { Low protein }}$} & \multicolumn{2}{|c|}{ High protein } & \multicolumn{2}{|c|}{$\underline{\text { Low protein }}$} \\
\hline & $\begin{array}{l}\text { Low } \\
\text { fiber }\end{array}$ & $\begin{array}{l}\text { High } \\
\text { fiber }\end{array}$ & $\begin{array}{l}\text { Low } \\
\text { fiber }\end{array}$ & $\begin{array}{l}\text { High } \\
\text { fiber }\end{array}$ & $\begin{array}{l}\text { Low } \\
\text { fiber }\end{array}$ & $\begin{array}{l}\text { High } \\
\text { fiber }\end{array}$ & $\begin{array}{l}\text { Low } \\
\text { fiber }\end{array}$ & $\begin{array}{l}\text { High } \\
\text { fiber }\end{array}$ \\
\hline \multicolumn{9}{|l|}{ Ingredients, \% } \\
\hline Yellow corn & 53.13 & 43.13 & 57.10 & 46.30 & 55.15 & 45.20 & 59.50 & 48.00 \\
\hline Soy-bean meal (44\% CP) & 33.30 & 32.50 & 30.00 & 28.50 & 28.25 & 25.00 & 21.50 & 19.00 \\
\hline Fish meal (72\% CP) & 1.50 & 1.00 & 0.25 & 0.25 & - & - & - & - \\
\hline Clover hay & 0.50 & 15.40 & 0.75 & 16.15 & 2.50 & 16.50 & 2.50 & 16.50 \\
\hline Wheat bran & 4.50 & 1.00 & 4.30 & 1.60 & 4.40 & 5.00 & 7.45 & 8.10 \\
\hline Plant oil & 4.00 & 4.00 & 4.00 & 4.00 & 6.00 & 6.00 & 6.00 & 6.00 \\
\hline Bone meal & 2.15 & 2.20 & 2.55 & 2.35 & 2.35 & 1.50 & 1.50 & 1.50 \\
\hline Limestone & 0.20 & 0.05 & 0.30 & 0.05 & 0.70 & 0.15 & 0.80 & 0.15 \\
\hline Premix & 0.30 & 0.30 & 0.30 & 0.30 & 0.30 & 0.30 & 0.30 & 0.30 \\
\hline Salt & 0.25 & 0.25 & 0.25 & 0.25 & 0.25 & 0.25 & 0.25 & 0.25 \\
\hline Methionine & 0.17 & 0.17 & 0.20 & 0.18 & 0.10 & 0.10 & 0.15 & 0.15 \\
\hline Lysine & - & - & - & 0.07 & - & - & 0.05 & 0.05 \\
\hline Total & 100 & 100 & 100 & 100 & 100 & 100 & 100 & 100 \\
\hline \multicolumn{9}{|l|}{ Composition } \\
\hline \multicolumn{9}{|l|}{ Analyzed $†$} \\
\hline Dry matter, \% & 91.30 & 91.43 & 90.75 & 90.78 & 93.13 & 93.08 & 93.15 & 93.07 \\
\hline Organic matter, \% & 84.29 & 83.22 & 83.66 & 82.80 & 87.02 & 87.08 & 87.13 & 86.54 \\
\hline Crude protein, \% & 21.04 & 21.00 & 19.05 & 19.01 & 18.08 & 18.03 & 16.04 & 16.02 \\
\hline Crude fiber, \% & 4.06 & 8.01 & 4.04 & 8.00 & 4.15 & 8.05 & 4.20 & 8.01 \\
\hline Ether extract, \% & 6.61 & 6.53 & 6.69 & 6.46 & 8.52 & 8.45 & 8.70 & 8.62 \\
\hline $\mathrm{N}$ - free extract, \% & 52.58 & 47.68 & 53.88 & 49.33 & 56.27 & 52.55 & 58.19 & 53.89 \\
\hline Crude ash, \% & 7.01 & 8.21 & 7.09 & 7.98 & 6.11 & 6.00 & 6.02 & 6.53 \\
\hline \multicolumn{9}{|l|}{ Calculated $\ddagger$} \\
\hline $\begin{array}{l}\text { Metabolizable energy, } \\
\text { Kcal/kg }\end{array}$ & 3008 & 2751 & 3007 & 2761 & 3120 & 2862 & 3128 & 2862 \\
\hline Calcium, \% & 1.06 & 1.07 & 1.01 & 1.03 & 0.82 & 0.81 & 0.86 & 0.87 \\
\hline Available phosphorous, \% & 0.45 & 0.45 & 0.46 & 0.45 & 0.31 & 0.33 & 0.32 & 0.33 \\
\hline Methionine, \% & 0.50 & 0.51 & 0.50 & 0.50 & 0.39 & 0.39 & 0.39 & 0.39 \\
\hline Lysine, \% & 1.13 & 1.17 & 1.10 & 1.11 & 0.85 & 0.95 & 0.89 & 0.87 \\
\hline
\end{tabular}

Statistical analyses:

To assess breed-type, sex and diet influences on live performance and slaughter traits and on fat partitioning, the data were analyzed by the General Linear Models procedures of SAS (SAS Institute, 1995) according to the following model

\footnotetext{
$Y_{i j k l}=\mu+B_{i}+S_{j}+D_{k}+(B S)_{i j}+(B D)_{i k}+(S D) j k+E_{i j k l}$

Where,

$\mathrm{Y}_{\mathrm{ijkl}}=$ weight $(\mathrm{g})$ or percentage of the component $\mathrm{Y}$ of the $\mathrm{ijkl}$ bird;

$\mu \quad=$ overall mean;
} 
$\mathrm{B}_{\mathrm{i}} \quad$ = fixed effect of the breed group $(\mathrm{i}=1,2)$;

$\mathrm{S}_{\mathrm{j}} \quad$ = fixed effect of the sex $(\mathrm{j}=1,2)$;

$\mathrm{D}_{\mathrm{k}} \quad$ = fixed effect of the diet $(\mathrm{k}=1 \ldots 4)$;

$(B S)_{i j}=$ the interactions between breed and sex;

$(\mathrm{BD})_{\mathrm{ik}}=$ the interactions between breed and diet;

(SD) $\mathrm{jk}=$ the interactions between sex and diet;

$\mathrm{E}_{\mathrm{ijkl}}=$ the random error assumed N.I.D. $\left(0, \sigma^{2} \mathrm{e}\right)$.

Duncan's multiple range test was used to test for significant differences between pairs of means.

Table 2

Means, standard deviations (SD), coefficient of variability (CV\%) and minimum and maximum values for live body weight and carcass traits in broiler chickens (Mittelwerte, Standardabweichungen, Variabilitätskoeffizienten, Minimum und Maximum-Werte für Lebendgewicht und Schlachtmerkmale bei Broilern)

\begin{tabular}{|c|c|c|c|c|c|}
\hline \multirow[b]{2}{*}{ Live body weight (g) } & \multirow{2}{*}{$\begin{array}{c}\text { Means } \\
2350.29\end{array}$} & \multirow{2}{*}{$\begin{array}{l}\mathrm{SD} \\
426.41\end{array}$} & \multirow{2}{*}{$\frac{\text { CV\% }}{18.14}$} & \multicolumn{2}{|c|}{ Range } \\
\hline & & & & 1400 & -3505 \\
\hline Carcass weight (g) & 1621.72 & 316.06 & 17.49 & 869 & -2552 \\
\hline Carcass muscle (g) & 951.12 & 203.91 & 21.44 & 468 & -1492 \\
\hline Carcass fat (g) & 364.04 & 86.52 & 23.77 & $182-$ & $-\quad 586$ \\
\hline Non-carcass fat (g) & 60.50 & 28.72 & 47.47 & 6.21 & $-\quad 151.25$ \\
\hline Total body fat (g) & 424.54 & 107.42 & 25.30 & 192.54 & - 696.98 \\
\hline Carcass bone (g) & 266.31 & 52.02 & 19.54 & 146 & -424 \\
\hline Boneless carcass (g) & 1315.16 & 275.73 & 20.97 & 714 & -2074 \\
\hline Fatless carcass (g) & 1217.43 & 251.45 & 20.65 & 626 & -1916 \\
\hline \multicolumn{6}{|c|}{ Carcass fat : non- carcass } \\
\hline \multicolumn{6}{|l|}{$\%$ of live weight } \\
\hline Carcass $^{1}$ & 68.87 & 2.59 & 3.77 & 55.23 & 74.77 \\
\hline Carcass $^{2}$ & 73.10 & 2.47 & 3.38 & 58.60 & 77.81 \\
\hline Giblet & 4.25 & 0.65 & 15.26 & 2.78 & 7.12 \\
\hline Total body fat & 18.04 & 3.14 & 17.42 & 11.46 & $-\quad 27.75$ \\
\hline Carcass fat & 15.48 & 2.43 & 15.72 & 9.98 & 25.47 \\
\hline Non-carcass fat & 2.55 & 1.11 & 43.57 & 0.27 & 5.97 \\
\hline \multicolumn{6}{|c|}{$\%$ of total body fat weight } \\
\hline Carcass fat & 86.25 & 4.79 & 5.56 & 71.01 & 97.78 \\
\hline Non-carcass fat & 13.75 & 4.79 & 34.83 & 2.22 & 26.99 \\
\hline \multicolumn{6}{|l|}{$\%$ of Non-carcass fat } \\
\hline Gizzard fat & 32.10 & 8.13 & 25.33 & 14.79 & $9-67.69$ \\
\hline Pad fat & 48.15 & 9.99 & 20.74 & 7.25 & -73.73 \\
\hline Visceral fat & 15.24 & 5.92 & 38.82 & 1.26 & $-\quad 31.21$ \\
\hline Heart fat & 4.51 & 2.94 & 65.32 & 0.50 & 19.32 \\
\hline
\end{tabular}

Results

Table 2 presents the means, standard deviations and coefficient of variation for live body weight, carcass fat and non-carcass fat. Live body weight at 8 weeks of age averaged $2350 \mathrm{~g}$ and ranged from 1400 to $3500 \mathrm{~g}$. The non-carcass fat and carcass fat constituted $2.6 \%$ and $15.5 \%$ of live weight, respectively. These depots 'total body fat' were totaling $18.1 \%$ of live body weight (Table 2). When fat depots expressed as a percentage of total body fat, it was found that carcass fat and non-carcass fat accounted for $86 \%$ and $14 \%$ of total body fat. The 
carcass fat to non-carcass fat ratio ranged from 2.7 to 44.1 with a mean of 7.6. Pad fat was the largest intra-abdominal fat depot, constituted $48.2 \%$ of noncarcass fat followed by gizzard fat 32.1.

Coefficient of variation for slaughter traits ranged from $3.4 \%$ for dressing percentage to $42.6 \%$ for non-carcass fat weight (Table 2 ).

Diet significantly affected feed intake and feed: gain ratios during growing, finishing and whole experimental periods. Birds fed diet 1 consumed more feed than those fed other diets. Feed: gain ratio for the whole experimental period (8-weeks) averaged 1.97, 1.95, 1.73 and 1.90 for diets 1,2,3 and 4, respectively. Birds fed diet 2 were more efficient in converting feed into live weight gain than those fed other diets (untabulated).

\section{Fat yields}

Total body fat: Expressed as a percentage of live body weight, the proportion of total body fat did not differ significantly between breed groups (Table 3).

Compared with males, females had significantly higher (9\%) percentage of total body fat (Table 3). These differences could be related to the earlier onset of fattening and rate of fattening of females.

Table 3

Means for non-carcass fat and carcass fat as percentage of live body weight and as a percentage of total body fat of broiler chickens by breed, sex and diet (Mittelwerte von Nicht-Muskelfett und Muskelfett in Prozent des Lebendgewichtes und des Gesamtfettgehaltes bei Broilern nach Rasse, Geschlecht und Fütterung)

\begin{tabular}{|c|c|c|c|c|c|c|c|c|c|c|c|c|c|c|}
\hline & \multicolumn{2}{|c|}{ Breed (B) } & \multicolumn{2}{|c|}{ Sex (S) } & \multicolumn{4}{|c|}{$\operatorname{Diet}(\mathrm{D})^{+}$} & \multicolumn{6}{|c|}{ Significance of difference } \\
\hline & Hubbard & Anak & Male & Female & HP-LF & HP-HF & LP-LF I & LP-HF & $\mathbf{B}$ & $\mathrm{S}$ & D & BS & BD & SD \\
\hline Total body fat (g) & 436.114 & 439.58 & 436.51 & 439.28 & $556.94 a$ & 337.18d & 468.69b & 383.70c & NS & NS & $* *$ & NS & NS & NS \\
\hline \multicolumn{15}{|c|}{$\begin{array}{l}\text { Percentage of live body } \\
\text { weight }\end{array}$} \\
\hline Gizzard fat & 0.79 & 0.85 & $0.73 a$ & $0.92 b$ & $0.99 a$ & $0.49 c$ & $1.01 \mathrm{a}$ & $0.80 b$ & NS & $*$ & $*$ & NS & NS & NS \\
\hline Heart fat & 0.10 & 0.10 & 0.10 & 0.11 & 0.11 & 0.08 & 0.11 & 0.11 & NS & NS & NS & NS & NS & NS \\
\hline Pad fat & 1.21 & 1.26 & 1.17 & 1.30 & $1.54 a$ & $0.87 c$ & $1.39 \mathrm{a}$ & $1.13 b$ & NS & NS & $* *$ & $*$ & NS & NS \\
\hline Intestine fat & 0.40 & 0.38 & $0.33 a$ & $0.44 b$ & 0.45 & 0.24 & 0.52 & 0.33 & NS & $* *$ & NS & NS & NS & NS \\
\hline Non-carcass fat & 2.51 & 2.61 & $2.34 a$ & $2.77 b$ & 3.09a & $1.68 \mathrm{c}$ & 3.03a & $2.38 \mathrm{~b}$ & NS & $* *$ & $* *$ & NS & NS & NS \\
\hline Carcass fat & 15.51 & 15.46 & $14.88 \mathrm{a}$ & 16.10b & $15.97 a$ & $13.78 \mathrm{~b}$ & 16.45a & $15.67 a$ & NS & $* *$ & $* *$ & NS & NS & $* *$ \\
\hline Total body fat & 18.01 & 18.06 & $17.22 \mathrm{a}$ & $18.87 b$ & $19.06 a$ & $15.46 \mathrm{~b}$ & $19.48 a$ & $18.05 a$ & NS & $* *$ & $* *$ & NS & NS & $*$ \\
\hline \multicolumn{15}{|c|}{$\begin{array}{l}\text { Percentage of total body } \\
\text { fat }\end{array}$} \\
\hline Gizzard fat & 4.28 & 4.57 & $4.10 \mathrm{a}$ & $4.75 b$ & $5.18 a$ & $3.05 c$ & $5.15 a$ & $4.24 \mathrm{~b}$ & NS & $* *$ & $* *$ & NS & NS & NS \\
\hline Heart fat & 0.57 & 0.57 & 0.58 & 0.55 & 0.58 & 0.50 & 0.58 & 0.60 & NS & NS & NS & NS & NS & NS \\
\hline Pad fat & 6.56 & 6.79 & 6.56 & 6.80 & 8.04a & $5.37 \mathrm{c}$ & $7.06 a$ & $6.18 b c$ & NS & NS & $* *$ & NS & NS & NS \\
\hline Intestine fat & 2.13 & 2.04 & 1.89a & $2.28 \mathrm{~b}$ & $2.33 a$ & $1.57 b$ & 2.61a & $1.79 b$ & NS & $*$ & $* *$ & $*$ & NS & NS \\
\hline Non-carcass fat & 13.53 & 13.97 & 13.13a & $14.38 b$ & $16.12 a$ & $10.49 \mathrm{c}$ & 15.41ab & b $12.84 b$ & NS & $*$ & $* *$ & NS & NS & NS \\
\hline Carcass fat & 86.47 & 86.03 & 86.87a & 85.62b & 83.88c & 89.51a & 84.59bc & c $87.16 b$ & NS & $*$ & $* *$ & NS & NS & NS \\
\hline
\end{tabular}

a, b, c means in raw bearing different superscripts differ significantly at $\mathrm{P}<0.05$.

*, ** $\mathrm{P}<0.05$ and $\mathrm{P}<0.01$, respectively; NS, not significant $(\mathrm{P}>0.05)$.

the abbreviations are defined in the text.

Birds fed diet 2 (high protein - high fiber) had significantly lower total body fat relative to live body weight than those birds fed other diets which were not significantly differed from each other (Table 3). Increasing level of fiber from 4 to 8\% had no significant effect on reducing total body fat percentage in birds given low protein diets.

Carcass and non-carcass fat depots: Differences in non-carcass fat and its component depots and carcass fat depots between breeds were found to be non-significant (Table 
3). Hubbard tended to have a smaller percentage of non-carcass fat than Anak, although the differences were not significant. Sex significantly affected deposition of fat (Table 3). Expressed as a percentage of live body weight, females had significantly higher proportions of gizzard fat, pad fat, intestine fat, non-carcass fat and carcass fat than males (Table 3). The differences between sexes in fat yields may have been the result of differences in stage of maturity.

There were significant differences between diets in the relative proportion of various fat depots (Table 3). Relative to live body weight birds fed diet 2 (high protein - high fiber) had significantly lower proportion of gizzard fat, pad fat, intra-abdominal fat and carcass fat than those fed other diets. Within each protein level, raising fiber \% in the diet resulted in lowering percentages of gizzard fat, intra- abdominal fat and carcass fat (Table 3).

\section{Fat partitioning among the depots}

The contributions of non-carcass fat and its components and carcass fat to total body fat are shown in Table 3. There were no significant differences between breeds in fat partitioning total body fat among the depots. The contribution of non-carcass fat increased, while that of carcass fat decreased with increasing of total body fat.

Sex of bird significantly influenced the partition of fatty tissues between depots (Table 3). As expected, males tended to partition more of their fat to carcass fat depots, whereas females tended to partition more of their fat to non-carcass fat depots.

Diet had significant effect on fat partitioning among the depots (Table 3). Birds fed high protein- high fiber diet tended to partition more of their fat to carcass fat depots and less to non-carcass fat depots.

\section{Genetic and nutritional Interactions}

Breed $x$ diet. Table 3 reveals that the breed $\mathrm{x}$ diet interaction was not significant for any of the fatness traits. The non-significant breed $x$ diet interactions for the above mentioned traits indicated that the effect of diet was similar in both breeds.

Breed $x$ sex. None of the fatness traits other than the intestinal fat as a percentage of total body fat (Table 3) were significantly influenced by breed $\mathrm{x}$ sex interaction. Irrespective of breed, the contribution of intestinal fat to total body fat in males was greater than in females and the differences between sexes were greater in Hubbard than in Anak (not shown).

Table 4

Means for carcass fat and total body fat relative to live body weight with significant sex $\mathrm{x}$ diet interactions (Mittelwerte von Muskelfett und Gesamtkörperfett in Beziehung zum Lebendgewicht mit signifikanten Geschlecht : Ernährung Interaktionen)

\begin{tabular}{ccccc}
\hline & \multicolumn{2}{c}{ High protein } & \multicolumn{2}{c}{ Low protein } \\
& Low fiber & High fiber & Low fiber & High fiber \\
\hline Males & & Carcass fat & \\
Females & 15.85 & 13.47 & 15.92 & 14.18 \\
Males / Females & 16.10 & 14.09 & 16.98 & 0.83 \\
& 0.98 & 0.96 & 0.94 & 17 \\
Males & & Total body fat & & 16.27 \\
Females & 18.90 & 14.99 & 18.56 & 0.82 \\
Males/ Females & 19.23 & 15.93 & 20.40 & 0.90 \\
\hline
\end{tabular}

Sex $x$ diet. Significant $(\mathrm{P}<0.05)$ sex $\mathrm{x}$ diet interactions were revealed by analysis of variance for carcass fat and total body fat relative to live body weight (Table 3). These 
indicated that the effect of diet on the above mentioned traits was dependent on the sex of bird and the differential responses in these traits may be more important than the main effects. The sexual dimorphism in low protein diets (with low or high fiber) for fat relative to live body weight is more pronounced than in high protein diets (Table 4). The significant interactions indicated that different sexes should have different diets to maximize profitability.

\section{Relationship among fat depots:}

Correlation coefficients among the major fat depots were calculated (Table 5). The upper off-diagonal elements were computed from fat depots as a percentage of total body fat, while the lower off-diagonal elements were computed from the absolute weight of the major fat depots. Total body fat weight was positively correlated with non-carcass fat and its component depot weights and percentages and carcass fat weight and but it was negatively correlated carcass fat percentage. Correlation between non-carcass fat weight and carcass fat weight was high and positive ( $r=0.65$,) while that between non-carcass fat percentage and carcass fat percentage was high and negative $(r=-1.0)$. The negative correlation between percentages of non-carcass fat and carcass fat suggest that selection against non-carcass fat may result in a relative increase in carcass fat depots (subcutaneous and intermuscular fat).

Table 5

Phenotypic correlation matrix for major fat depots $^{+}$(Matrix phänotypischer Korrelationen zwischen den wichtigsten Fettdepots)

\begin{tabular}{lccccccc}
\hline & $\begin{array}{c}\text { Gizzard } \\
\text { fat }\end{array}$ & $\begin{array}{c}\text { Pad } \\
\text { fat }\end{array}$ & $\begin{array}{c}\text { Intestinal } \\
\text { fat }\end{array}$ & $\begin{array}{c}\text { Heart } \\
\text { fat }\end{array}$ & $\begin{array}{c}\text { Non carcass } \\
\text { fat }\end{array}$ & $\begin{array}{c}\text { Carcass } \\
\text { fat }\end{array}$ & $\begin{array}{c}\text { Total body } \\
\text { fat }\end{array}$ \\
\hline Gizzard fat & & & & & & & \\
Pad fat & 0.44 & 0.56 & 0.26 & 0.71 & -0.71 & 0.28 \\
Intestinal fat & 0.62 & & 0.35 & 0.25 & 0.86 & -0.86 & 0.40 \\
Heart fat & 0.42 & 0.44 & & 0.12 & 0.67 & -0.67 & 0.29 \\
Non carcass fat & 0.86 & 0.91 & 0.75 & & 0.35 & -0.35 & 0.03 \\
Carcass fat & 0.54 & 0.61 & 0.47 & 0.31 & & -1.00 & 0.41 \\
Total body fat & 0.66 & 0.74 & 0.57 & 0.41 & 0.65 & & -0.41 \\
\hline${ }^{+}$Above diagonal based on percentages of total body fat, below diagonal based on weights &
\end{tabular}

Relationship between live performance parameters and fat deposition and carcass attributes. Estimates of phenotypic correlation coefficient between growth-related traits and various fat depots are shown in Table 6.

Live body weight was positively correlated with carcass fat weight and noncarcass fat depots The phenotypic correlation between live body weight with non-carcass fat, carcass fat and total body fat were $0.48,0.78$ and 0.76 , respectively. The correlations of feed intake with live body weight during growing, finishing and whole periods were $0.53,0.73$ and 0.78 , respectively (not shown).

Average daily gains during grower and finisher periods followed the same trends observed for live body weight in that they were positively correlated with noncarcass fat depots and carcass fat depot. Correlation with carcass fat was higher than that with non-carcass fat. Also, the daily gain had positive and high correlation with all carcass traits other than leg muscle as a percentage of total carcass muscle. Correlations during finishing period were higher than those during growing period. 
Feed consumption during the finisher period (4-8 weeks) was positively correlated with each of non-carcass fat and its components, carcass fat and total body fat. The correlation with carcass fat was higher than with non-carcass fat. The correlation coefficient between feed consumption and total body fat was 0.57.

\section{Table 6}

Correlation coefficients between major fat depot weights, carcass traits at 8 weeks of age and average daily gain, feed: gain ratio during grower and finisher periods and feed consumption during finisher period and whole experimental period (Korrelationskoeffizienten zwischen den wichtigsten Fettdepots, Schlachtmerkmalen acht Wochen alter Tiere, täglicher Zunahme, Fütterung und Wachstumsmerkmalen während der Endperiode und des gesamten Versuchsabschnittes)

\begin{tabular}{|c|c|c|c|c|c|c|c|}
\hline \multirow[b]{2}{*}{ Component } & \multirow{2}{*}{$\begin{array}{c}\text { Live body } \\
\text { weight at } \\
8 \text { weeks }\end{array}$} & \multicolumn{2}{|c|}{ Average daily gain } & \multicolumn{2}{|c|}{ Feed: gain ratio } & \multicolumn{2}{|c|}{ Feed consumption } \\
\hline & & $\begin{array}{l}\text { Grower } \\
(1-4 \text { wk) }\end{array}$ & $\begin{array}{l}\text { Finisher } \\
\text { (4-8 wk) }\end{array}$ & $\begin{array}{l}\text { Grower } \\
\text { (1-4 wk) }\end{array}$ & $\begin{array}{l}\text { Finisher } \\
\text { (4-8 wk) }\end{array}$ & $\begin{array}{l}\text { Finisher } \\
(4-8 \mathrm{wk})\end{array}$ & $\begin{array}{l}\text { Whole } \\
\text { (1-8 wk) }\end{array}$ \\
\hline Gizzard fat & 0.35 & 0.32 & 0.30 & -0.42 & 0.12 & 0.36 & 0.34 \\
\hline Pad fat & 0.50 & 0.45 & 0.44 & -0.37 & 0.14 & 0.52 & 0.52 \\
\hline Intestinal fat & 0.31 & 0.34 & 0.24 & -0.27 & 0.08 & 0.31 & 0.32 \\
\hline Heart fat & 0.30 & 0.31 & 0.25 & -0.21 & -0.02 & 0.22 & 0.24 \\
\hline Non carcass fat & 0.48 & 0.45 & 0.42 & -0.42 & 0.14 & 0.49 & 0.49 \\
\hline Carcass fat & 0.78 & 0.57 & 0.74 & -0.33 & -0.17 & 0.54 & 0.57 \\
\hline Total body fat & 0.76 & 0.58 & 0.71 & -0.38 & -0.10 & 0.57 & 0.59 \\
\hline Carcass muscle & 0.88 & 0.63 & 0.85 & -0.27 & -0.15 & 0.61 & 0.69 \\
\hline Carcass bone & 0.83 & 0.61 & 0.79 & -0.22 & -0.13 & 0.61 & 0.66 \\
\hline Boneless carcass & 0.90 & 0.64 & 0.86 & -0.31 & -0.17 & 0.65 & 0.69 \\
\hline Fatless carcass & 0.89 & 0.64 & 0.86 & -0.27 & -0.27 & 0.65 & 0.69 \\
\hline Breast muscle \%† & 0.29 & 0.19 & 0.29 & -0.14 & -0.06 & 0.21 & 0.21 \\
\hline Leg muscle \% & -0.14 & 0.09 & -015 & 0.14 & -0.01 & -0.13 & -0.11 \\
\hline Breast muscle & 0.84 & 0.59 & 0.82 & -0.27 & -0.15 & 0.61 & 0.65 \\
\hline Leg muscle & 0.86 & 0.62 & 0.83 & -0.25 & -0.16 & 0.62 & 0.66 \\
\hline Expensive & & & & & & & \\
\hline muscle $\ddagger$ & 0.87 & 0.62 & 0.84 & -0.26 & -0.16 & 0.63 & 0.67 \\
\hline Muscle: bone ratio & 0.28 & 0.16 & 0.28 & -0.17 & -0.07 & 0.19 & 0.19 \\
\hline $\begin{array}{l}\text { Non-carcass fat: } \\
\text { carcass fat ratio }\end{array}$ & 0.12 & 0.21 & 0.05 & -0.33 & 0.29 & 0.25 & 0.23 \\
\hline
\end{tabular}

$\dagger$ Percentage of total carcass muscle

Feed intake was significantly correlated with breast muscle absolute weight and breast muscle as a percentage of total carcass muscle, expensive muscle (breast and thigh) weight and muscle: bone ratio. Gain and feed intake were highly positively correlated: $0.80,0.73$ and 0.78 during growing, finishing and whole experimental periods, respectively (not shown).

The phenotypic correlation between feed intake and feed: gain ratio during growing, finishing and whole periods were $0.32,0.42$ and 0.54 , respectively (not shown).

Feed: gain ratio was negatively correlated with non-carcass fat depots and carcass fat depot. The correlations were higher during grower period than during finisher period. The correlation between feed: gain ratio with non-carcass fat, carcass fat and total body fat were $-0.42,-0.33$ and -0.38 , respectively.

\section{Discussion}

\section{General considerations}

Body fat and its component depots is a dynamic trait that varies with genotype, stage of maturity, nutrition and other factors. In present study non-carcass fat 
accounted for $2.6 \%$ of live body weight and $14 \%$ of total body fat. This fat depot could alter dressing yield, detract from carcass quality and would be of concern to various segments of poultry meat industry. The present results are in line with that of HEATH et al. (1980) who found that fat pad was the greatest contributor to non-carcass fat followed by gizzard fat.

Reduction of carcass fat and non-carcass fat accumulation is a major goal in the continued improvement of broilers. In a literature review by LEENSTRA (1984) the coefficient of variation of the abdominal fat weight of broiler reared in the same environment varied from 24 to $47 \%$. The large variability of this trait along with its high heritability offers favorable prospects for selection against this trait LEENSTRA et al. (1986).

\section{Fat yields}

Total body fat: In the present study, Hubbard and Anak tended to have similar the proportion of total body fat. Significant differences between commercial broilers strains in total fat content independent of body weight have been reported by VAN MIDDELKOOP et al. (1977).

Carcass and non-carcass fat depots: In the present study Hubbard and Anak did not differ significantly in carcass fat and non-carcass fat yields. The absence of breed effect on these traits is probably due to the two breeds did not differ very much genetically. Also, SMITH and PESTI (1998) found that strain had no significant effect on the percentage or weight of abdominal fat pads. Differences between meat-type and layer type chickens in fat yields have been observed. MAHMOUD (1985) reported significant differences between dual-purpose strains (Gimmizah and Bandars) and layer strains (Silver and Golden Montazah) in abdominal fat as a percentage of live body weight. Broiler type strain tended to have more than twice as relative amount of abdominal fat as layer-type chickens (MARCH, 1984). GRIFFIN et al. (1987) reported significant differences between broiler chickens and layer-strain chickens. They found that abdominal fat constituted $1.5 \%$ of live body weight in broilers, while corresponding value in layer-type was $0.5 \%$. These differences could be related to differences in propensity to fatten.

In the present study female birds consistently had a much higher percentage of carcass fat and non-carcass fat than did males DEATON et al. (1983) found that within each dietary energy level, the abdominal fat in females was higher percentage of live body weight than in males. Also, BECKER et al. (1981b) reported that compared with females, males had lower percentage of carcass fat (12 vs. 13.7\%). These differences between sexes probably arise from metabolic differences and from differences in the onset of fattening.

The present study showed that non-carcass fat and carcass fat yields were greatly depressed through feeding birds high protein- high fiber diets. BARTOV and PLAVNIK (1998) found that relative abdominal fat pad weight increased significantly by increasing energy to protein ratio in the diet.

\section{Fat partitioning among the depots}

Breeds have been thought to influence fat partition. In the present study breeds tended to have similar patterns of fat partitioning. The absence of breed differences in fat partitions could be related to their slaughtered at similar stage of physiological development. SHAHIN et al. (1990) reported significant differences between broilertype (Hubbard) and dual purpose-type (Fayoumi) in fat partitioning. They found that 
compared with Fayoumi, Hubbard tended to partition more of their fat to non-carcass fat depots and less of their fat to subcutaneous fat.

In the present study, compared to males, females tended to partition more of their fat to non-carcass fat depots. BECKER et al. (1981a) found no significant differences between males and females in partition of total fat. They found that carcass fat represented $71 \%$ of total fat in males and $70 \%$ in females and the non-carcass fat made the balance.

The effect of nutrition on fat partitioning in chickens have not been studied thoroughly and results from controlled experiments are scarce. Results obtained in this study clearly demonstrate the possibiliy of depressing fat deposition and alterning fat partition by shifiting more of waste fat (non-carcass fat) into or onto carcass where it is more valuable by feeding birds high protein accompanied with high fiber diets.

\section{Genetic and nutritional Interactions}

Breed $\mathrm{x}$ sex, breed $\mathrm{x}$ diet and sex $\mathrm{x}$ diet interactions did not significantly influence most of fatness traits indicating that the factors under consideration act independently of each other's. The absence of significant interactions on these traits indicated that the effect of diet was essentially the same regardless of breed and sex and indicated that differences between diets tended to be similar for different breeds and sexes. SMITH et al. (1998) showed a non-significant strain by protein interaction for abdominal fat pad yield. These results are contrary to those reported by LEENSTRA (1984) who indicated that the effect of diet on fat deposition vary with broiler strains. Also, MARKS (1990) reported significant genotype (commercial broiler and unselected chickens) by diet (high protein and high energy) interactions for percent abdominal fat. Significant sex $\mathrm{x}$ diet interactions was found for carcass fat relative to live body weight. This indicated that the effect of diet on the above mentioned trait was dependent on the sex of bird and the differential responses in these traits may be more important than the main effects. Somewhat similar findings have been reported by AJANG et al. (1993) who showed a significant diet $\mathrm{x}$ sex interaction, with males showing a greater response to protein increase than females.

\section{Relationship among fat depots:}

In the present study total body fat was negatively correlated with carcass fat percentage and positively correlated with non-carcass fat percentage. The correlation coefficient between non-carcass fat weight and carcass fat weight reported in present study was comparable to that reported by MENDES et al. (1995). The negative correlation between carcass fat percentage and non-carcass fat percentage suggest that selection against non-carcass fat may result in a relative increase in carcass fat depots (subcutaneous and intermuscular fat). CAHANER et al. (1986) found that selection against abdominal fat resulted in a decrease in other fat depots. It is worth mentioning that any sound decisions about the effect of selection on reduction of any fat depot should be accompanied by the basis of comparisons (i.e. absolute weights or percentage of live weight or percentage of total body fat).

\section{Relationship between live performance parameters and fat deposition and carcass attributes}

The positive correlations between live body weight and each of non-carcass fat and carcass fat depots reported in this study indicates that selection for increased live body weight will be accompanied by undesirable increases in these fat depots. In broiler chickens, the correlation coefficient between live body weight 
and abdominal fat weight was 0.50 (VAN MIDDELKOOP et al., 1977), and 0.49 and 0.53 for males and females, respectively (BECKER et al., 1981a). Also, LEENSTRA et al. (1986) estimated the correlation between live body weight and abdominal fat weight as 0.46 . The positive correlation between live body weight and feed intake reported in this study was similar to that reported by WANG et al. (1991).

The positive correlation between gain and feed intake reported in this study was similar to that reported by CHAMBERS et al. (1983).

In the present study the correlation between feed intake and feed: gain ratio was positive and high. Similarly LEENSTRA et al. (1986) reported moderate positive correlation between these traits. WANG et al. (1991) reported negative correlation between feed intake and gain: feed ratio $\left(r_{g}=-0.51\right.$ in the sire population and -0.22 in the dam population). It is essential to define measures of feed efficiency (gain: feed) or feed utilization 'conversion' (feed: gain) when comparing results from different literature sources.

In the present study feed conversion ratios was negatively correlated with muscling and bone traits. It was positively correlated with feed intake, but as expected, negatively with daily gains during various stages of development, which imply that slower growing birds were less efficient than the more rapidly growing birds. The negative correlations imply that the more efficient birds will have less non-carcass and carcass fat depots.

In conclusion, The present study and that of SHAHIN and ABD EL AZEEM (2005) show that fat yields, distribution and partition patterns were similar in Hubbard and Anak, but these patterns were different in males and females. The total amount of body fat and its partitioning among the depots was manipulated by diet, in that non-carcass fatness and carcass fatness were greatly depressed and favorable fat partition (i.e. more carcasses fat and less non-carcass fat) was achieved via feeding birds high protein accompanied with high fiber diet. Differences in fat yields and partition may affect carcass quality, acceptability and value and the accuracy of prediction total body fat from non-carcass fat. The sexual dimorphism for carcass fat and total body fat yields were more pronounced on diet low in protein than on diet high in protein.

\section{References}

AJANG, O.A.; PRIJONO, S.; SMITH, W.K.:

Effect of dietary protein content on growth and body composition of fast and slow feathering broiler chickens. British Poultry Science 34 (1993), 73-91

AOAC

Association of Official Analytical Chemists: Official Methods of analysis of the Association of Official Analytical Chemists, Washington, DC. (1990)

BARTOV, I.; PLAVNIK, I.:

Moderate excess of dietary protein increases breast meat yield of broiler chicks. Poultry Science $\mathbf{7 7}$ (1998), 680- 688

BECKER, W.A.; SPENCER, J.V.; MIROSH, L.W.; VERSTRATE, J.A.:

Abdominal and carcass fat in five broiler strains. Poultry Science 60 (1981a), 693-697

BECKER, W.A.; SPENCER, J.V.; MIROSH, L.W.; VERSTRATE, J.A.:

Specific gravity, carcass fat, abdominal and carcass fat , and yield data in broiler chickens. Poultry Science $\mathbf{6 0}$ (1981b), 2045- 2052

CAHANER, A.; NITSAN, Z.; NIR, I.:

Weight and fat content of adipose and nonadipose tissues in broilers selected for or against abdominal adipose tissue. Poultry Science 65 (1986), 215-222

CHAMBERS, J.R.; FORTIN, A.; GRUNDER, A.A.: 
Relationships between carcass fatness and feed efficiency and its component traits in broiler chickens. Poultry Science 62 (1983), 2201-2207

DEATON, J.W.; MCNAUGHTON, J.L.; LOTT, B.D.:

The effect of dietary energy level and broiler weight on abdominal fat. Poultry Science 62 (1983), 2394-2397

FISHER, C.:

Fat deposition in broilers. In: J. WISEMAN (Ed.) Fats in Animal Nutrition, Butterworth, Nottingham, England, PP. 437-470. (1984)

GRIFFIN, H.D.; BUTTERWITH, S.C.; GODDAR, C.:

Contribution of lipoprotein lipase to differences in fatness between broiler and layer-strain chickens. British Poultry Science 28(1987), 197-206

HEATH, J.L.; COVEY, R.C.; OWENS, S.L.:

Abdominal leaf fat separation as a result of evisceration of broiler carcasses. Poultry Science 59 (1980), 2456-2461

KHANTAPRAB, S; NIKKI, T; NOBUKUNI, K.:

Effect of restricted feed intake on the growth of muscle and fat deposition in broiler chickens. Japanese Poultry Science 34 (1997), 363-372

LEENSTRA, F.R.:

Influence of diet and genotype on carcass quality in poultry, and their consequences for selection. In: HARESIGN W., COLE D.J.A. (Eds.). Recent advances in animal nutrition. Butterworth, London, England. PP 3-16. (1984)

LEENSTRA, F.R.:

Effect of age, genotype and environment on fat deposition in broiler chickens- a review. World's Poultry Science Journal 42 (1986), 12-25

LEENSTRA, F.R.; VEREIJKEN, P.F.G.; PIT, R.:

Fat deposition in broiler sire strain. 1. Phenotypic and genetic variation in, and correlations between, abdominal fat, body weight, and feed conversion. Poultry Science 65 (1986), 1225-1235

LEESON, S.; CASTON, L.; SUMMERS, J.D.:

Broiler response to diet energy. Poultry Science 75 (1996), 529- 535

MAHMOUD, T.H.; FARGHALY, M.; RIZK, R.E.:

Influence of strain on abdominal fat and their relation to carcass composition. Egyptian Poultry Science Journal 5 (1985), 86-96

MARCH, B.E:

Plasma triglyceride and glucose clearance in broiler-type and White Leghorn chickens with different degree of adiposity. Poultry Science 58 (1984), 1586-1593

MARKS, H.L. :

Genotype by diet interactions in body and abdominal fat weight in broilers. Poultry Science 69 (1990), 879-886

MENDES, A.A.; ANCONA, L.H.; LAVEAGA, A.E.; FRANCO, J.G.:

Effect of energy: protein ration in the diet on abdominal fat, specific gravity and chemical composition of the carcass of broiler chickens. Veterinaria -e-Zootecnia 7 (1995), 41-48

NRC

Nutrient Requirements of Poultry. 9 th Edition. National Academy Press, Washington, D.C., U.S.A (1994)

SAS

SAS User's Guide. Statistical Analysis System Institute, Inc., Cary, NC, USA. (1995)

SHAHIN, K.A.; ABDALLAH, O.Y.; SHEMEIS, A.R.:

Genetic influences on growth and partition of fat between depots and its distribution in fowl carcasses.

Reproduction Nutrition Development 30 (1990), 673- 681

SHAHIN, K.; ABD EL AZEEM, F.:

Effects of breed, sex and diet and their interactions on carcass composition and tissue weight distribution of broiler chickens. Arch. Tierz., Dummerstorf 48 (2005) 6, 612-626

SMITH, E.R.; PESTI, G.M. :

Influence of broiler strain cross and dietary protein on the performance of broilers. Poultry Science $\mathbf{7 7}$ (1998), 276-281

SMITH, E.R.; PESTI, G.M.; BAKALLI, R.I.; WARE, G.O.; MENTEN, J.F.M.:

Further studies on the influence of genotype and dietary protein on the performance of broilers. Poultry Science 77 (1998), 1678-1687

VAN MIDDELKOOP , J.H.; KUIT, A.R.; ZEGWAARD, A.:

Genetic factors in broiler fat deposition, In: BOORMAN K.N. WILSON B.J. ( Eds.), Growth and Poultry Meat Production. British Poultry Science Edinburgh, PP. 131-143. (1977)

WANG, L.; MCMILLAN, I.; CHAMBERS, J.R.: 
Genetic correlations among growth, feed, and carcass traits of broiler sire and dam populations. Poultry Science 70 (1991), 719- 725

WISEMAN, J.; LEWISE, C.E. :

Influence of dietary energy and nutrient concentration on the growth of body weight and carcass components of broiler chickens. Journal of Agricultural Science 131(1998), 361-371

Received: 2004-06-14

Accepted: 2006-02-27

Author's addresses

Prof. Dr. KARIMA A. SHAHIN*

Department of Animal production, Faculty of Agriculture, Ain Shams University,

P.O. Box 68, Hadayek Shoubra, 11241 Cairo, Egypt

*Corresponding Author

E-Mail: Shahin_ka@hotmail.com

Dr. FATHY ABD EL AZEEM

Department of Poultry production, Faculty of Agriculture, Ain Shams University, P.O. Box 68, Hadayek Shoubra, 11241 Cairo, Egypt 